\title{
Physiological correlates of ethanol self-selection by rats*
}

\author{
STEVEN BELENKO† and STEPHEN C. WOODS \\ Columbia University, New York, New York 10027
}

\begin{abstract}
High-drinker and low-drinker rats were given $1.2 \mathrm{~g} / \mathrm{kg}$ of ethanol intraperitoneally. Subsequent blood-alcohol measurement showed that low-drinker rats had a significantly higher level than high-drinker rats at $15 \mathrm{~min}$ postinjection. Previous studies measured ethanol levels starting at $60 \mathrm{~min}$ postinjection and reported no differences for high drinkers and low drinkers. The present results are interpreted to account for the observed behavioral differences between high-drinker and low-drinker rats.
\end{abstract}

It is a general observation that rats show wide variability in their consumption of ethanol (EtOH) in a self-selection paradigm with water as an alternate choice. Some rats will take most of their daily water requirements in the form of a low-concentration $\mathrm{EtOH}$ solution (high drinkers), whereas other animals will barely sample the EtOH (low drinkers). The reasons for this difference in behavior are not clear, although many people believe that much of the variation is due to genetic factors involving metabolic capacity and possibly gustatory factors (Eriksson, 1958; Rodgers, 1966).

The invariant effect of EtOH intake is an increase in blood-alcohol levels. Since blood-alcohol level is closely correlated with the behavioral effects of EtOH, it is worthwhile to investigate possible differences in EtOH tolerance between high-drinker and low-drinker rats, as determined by blood-alcohol measurements. Earlier research on rats (Segovia-Riquelme, Campos, Solodkowska, Gonzalez, Alvarado, \& Mardones, 1962; Segovia-Riquelme, Vitale, Hegsted, \& Mardones, 1956) and mice (Rodgers, 1967; Rodgers \& McClearn, 1962; Schlesinger, 1966) found no differences in the overall rate of metabolism in high-drinker and low-drinker animals. With one exception (Rodgers, 1967), these studies utilized labeled ethanol-1-14 $\mathrm{C}$ and measured ${ }^{14} \mathrm{CO}_{2}$ excretion. Criticisms of this method of analyzing ethanol metabolism have been presented elsewhere (Kalant, 1971). Furthermore, in several of the experiments (Rodgers, 1967; Segovia-Riquelme et al, 1962; Segovia-Riquelme et al, 1956), measurement did not begin until at least $1 \mathrm{~h}$ following $\mathrm{EtOH}$ injection. Any blood-alcohol differences before that time would not have been detected.

In the present experiment, evidence is presented for the first time of a possible physiological basis for differences in EtOH consumption in high- and low-drinker rats. Low-drinker rats had a significantly

\footnotetext{
*This research was supported by NIH Grant AM 15647 to S. Woods.

$\doteqdot$ Requests for reprints should be addressed to S. Belenko, Department of Psychology, Columbia University. New York. N.Y. 10027.
}

higher peak blood-alcohol level than did high-drinker rats 15 min following an intraperitoneal EtOH injection. There is thus a possible initial facilitation of absorption of EtOH from the peritoneal cavity in low-drinker rats (or possibly a more rapid equilibration of EtOH between the blood and the water of other tissues in high-drinker rats), which could account for the observed differences in EtOH consumption behavior. Low-drinker rats might have an aversion to EtOH because of the initial higher blood-alcohol levels attained following consumption.

\section{METHOD}

\section{Selection of Animals}

Eighteen female Charles River rats, aged 9 months at the onset of the experiment, were offered a choice between a $5 \%(\mathrm{v} / \mathrm{v})$ $\mathrm{EtOH}$ solution and water for a period of 2 weeks. A three-bottle random rotation method was utilized to control for position preference (Myers \& Holman, 1966). Food (Purina Lab Chow) was available ad lib during this period.

From this original group, four high-drinker and four low-drinker rats were chosen on the basis of a comparison of mean daily intake of $5 \% \mathrm{EtOH}$ to mean daily water intake. Some of the problems of measuring $\mathrm{EtOH}$ "preference" are discussed by Belenko and Woods (in press). High-drinker rats tended to derive most of their fluid requirement from the EtOH solution, while low-drinker rats barely consumed any EtOH at all. Table 1 summarizes the consumption data for these two groups. Total fluid consumption was not reliably different between the two groups.

\section{Experimental Procedure}

The eight unanesthetized rats (four high-drinker and four low-drinker rats) were injected intraperitoneally with $1.2 \mathrm{~g} / \mathrm{kg}$ of EtOH in $20 \%$ saline $(\mathrm{v} / \mathrm{v})$. Blood samples $(10 \mu \mathrm{l})$ were milked from the tail in the manner of Woods, Makous, and Hutton (1969) prior to the injection and at $15,30,60,120$. and $240 \mathrm{~min}$ postinjection. A total of three such series of blood-alcohol determinations, spaced at least 2 days apart. were made for each rat.

Table 1

Daily Fluid Consumption [ml/100 g Body Weight $(M \pm S E M)]$

\begin{tabular}{lccr} 
& $5 \% \mathrm{EtOH}$ & $\mathrm{H}_{2} \mathrm{O}$ & \multicolumn{1}{c}{ Total } \\
\hline High Drinker & $9.0 \pm .87$ & $1.9 \pm .62$ & $10.9 \pm 1.39$ \\
Low Drinker & $1.1 \pm .23$ & $8.5 \pm .86$ & $9.6 \pm .85$ \\
\hline
\end{tabular}




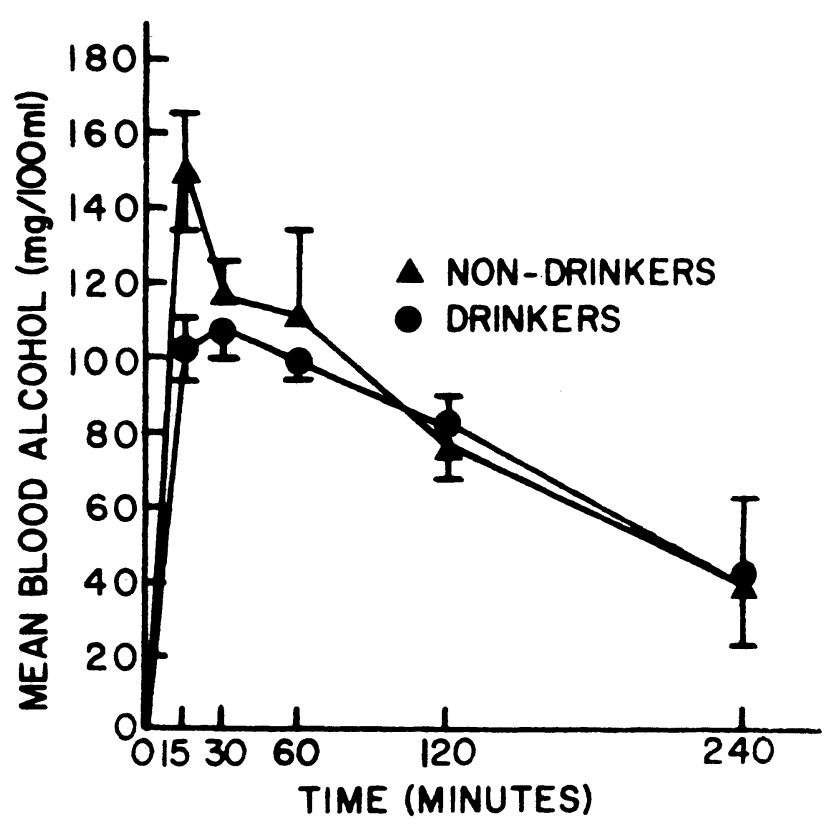

Fig. 1. Blood alcohol levels (mean $\pm S E M$ ) for drinker and nondrinker rats following the intraperitoneal administration of $1.2 \mathrm{~g} / \mathrm{kg}$ of ethanol. Drinker and nondrinker refers to the high-drinker and low-drinker rats used in the present study.

Blood-alcohol determinations were made by a modification of the distillation method of Lester and Grcenberg (1958). which permitted multiple simultaneous determinations. Previous calibration had shown the system to be accurate to within $1 \%-2 \%$ error.

\section{RESULTS}

The results are summarized in Fig. 1, in which mean blood-alcohol levels are presented for the two groups over the 4-h postinjection period. Fifteen minutes after the injection, the blood-alcohol level of the low-drinker rats was $150 \mathrm{mg} / 100 \mathrm{ml}$, whereas that of the high drinkers was $103 \mathrm{mg} / 100 \mathrm{ml}$. The difference was significant $(\mathrm{t}=2.72, \mathrm{df}=19, \mathrm{p}<.02)$. At 30 and $60 \mathrm{~min}$ postinjection, blood-alcohol levels were still slightly higher in the nondrinkers, although the difference was not significant. Beginning at $90 \mathrm{~min}$ postinjection, the two curves were virtually identical. The overall rate of disappearance of $\mathrm{EtOH}$ for both groups was approximately $200 \mathrm{mg} / \mathrm{kg} / \mathrm{h}$, which is slightly lower than previously published values for the rat (Aull, Roberts, \& Kinard, 1956). Inter-S variability was fairly high, as has been noted previously (Meek, Majchrowicz, \& Lipton, 1967).

\section{DISCUSSION}

The results of this experiment demonstrate a possible physiological basis for differences in ethanol self-selection behavior in rats. Previous studies examining
EtOH metabolism in rats by measuring ${ }^{14} \mathrm{CO}_{2}$ excretion reported no difference in $\mathrm{EtOH}$ metabolism rates between high-drinker and low-drinker rats (Segovia-Riquelme et al. 1962: Segovia-Riquelme et al, 1956). In mice also, no differences in rate of metabolism between high- and low-preference strains have been found. In those experiments, either ${ }^{14} \mathrm{CO}_{2}$ excretion (Rodgers \& McClearn, 1962: Schlesinger, 1966) or blood-alcohol levels (Rodgers, 1967) were measured. However, measurements were not begun until $60 \mathrm{~min}$ (Segovia-Riquelme et al, 1962: Segovia-Riquelme et al, 1956) or $75 \mathrm{~min}$ (Rodgers, 1967) after the injection in those experiments. Possible blood-alcohol differences occurring beforc 1 h would have been missed by these methods. Indeed, the present results confirm that no difference in $\mathrm{EtOH}$ metabolism exists beginning $1 \mathrm{~h}$ postinjection; the major difference in blood-alcohol levels, and perhaps the vital difference for behavior, occurs within 30 min postinjection and accounts for the earlier inconclusive results.

Hence, it is possible that the lack of much EtOH consumption by low-drinker rats may be due to an initial elevated blood-alcohol level following consumption, a level which may be aversive. It has been frequently observed that rats can associate aversive physiological effects with previously consumed fluids despite temporal delays in the onset of the effects (Revusky \& Garcia, 1970). That the elevated blood-alcohol level in low-drinker rats is not only characteristic of IP loads is supported by a previous study showing that low drinkers had a higher blood-alcohol level 30 min after oral consumption of a $5 \%$ EtOH solution with a fluid-deprivation schedule (Belenko, unpublished data). The etiology of the present results is not clear. The possibility that they may reflect differences in rate of absorption from the peritoneal cavity cannot be totally discounted. Rodgers (1966) has studied blood-alcohol levels in mice after an intravenous dose and found no significant difference in rate of metabolism between high- and low-preference strains. However, absorption of $\mathrm{EtOH}$ from the peritoneal cavity is extremely rapid and may approximate an intravenous injection (Kalant, 1971). Studies in this laboratory of EtOH tolerance curves following intracardiac administration in rats show a similar time course with respect to peak blood alcohol level as with IP loads (Belenko, in preparation). Thus, it is unlikely that absorption differences can totally account for the differences between high-drinker and low-drinker rats obtained in the present experiment, although an examination of blood-alcohol levels following an intragastric EtOH load would help to clarify the possible mechanisms. A second possibility is that the rate of equilibration of EtOH from blood to tissue is more rapid in high-drinker rats.

Cicero et al (1971) found no difference in either peak blood-alcohol level or rate of disappearance of EtOH from the blood between seven "high-alcohol" and two 
"low-alcohol" rats following an IP injection of $2.5 \mathrm{~g} / \mathrm{kg}$ of EtOH. However, these two "low-alcohol" rats were consuming up to $6 \mathrm{~g} / \mathrm{kg} /$ day of $7 \% \mathrm{EtOH}$ during a chronic consumption phase, an amount which is considerably more than the low-drinker rats in the present experiment ever consumed. Furthermore, the differences in dose $(2.5 \mathrm{~g} / \mathrm{kg}$ vs $1.2 \mathrm{~g} / \mathrm{kg})$ and concentration of the load $(25 \%$ vs $20 \%)$ make comparisons difficult.

The initial step in the metabolism of EtOH is via the enzyme, alcohol dehydrogenase (ADH) and occurs primarily in the liver. Thus, differences in blood-alcohol levels may reflect differences in $\mathrm{ADH}$ activity. A correlation between EŁOH preference and hepatic ADH activity in mice has been noted (McClearn, Bennett, Herbert, Kakihana, \& Schlesinger. 1964; Rodgers, McClearn, Bennett, \& Herbert, 1963), with high-preference strains showing the highest level of ADH activity and low-preference strains the lowest, even in the absence of EtOH consumption. Liver weight is correlated with ADH activity and a correlation has been found between liver weight and the capacity to metabolize $\mathrm{EtOH}$ in a high-preference mouse strain (Thiessen, Whitworth, \& Rodgers, 1967). The importance of ADH activity and liver weight in EtOH self-selection in rats is not clear, but it has been suggested that hepatic ADH activity does not correlate well with the rate of $\mathrm{EtOH}$ metabolism in the intact animal (Maichrowicz, Lipton. Meek. \& Hall, 1968; Wilson, 1967).

There is some evidence that ADH activity increases and then decreases in rats after chronic EtOH consumption (Dajani, Danielski, \& Orten, 1963; Figueroa \& Klotz, 1962), and thus, the high-drinker rats in the present experiment might have had increased $\mathrm{ADH}$ activity. However, they had not had EtOH for at least 5 weeks prior to the blood-alcohol study, and any induced increase in ADH activity would be attenuated at that time (cf. McClearn et al, 1964). Furthermore, the similarity in overall metabolism rate between the two groups suggests little difference in metabolic capacity. It is thus doubtful that the present results can be fully explained by differences in enzymatic activity, although further research in $\mathrm{ADH}$ activity in rats is needed.

\section{REFERENCES}

Aull, J. C., Jr., Roberts, W. C., Jr., \& Kinard, F. W. Rate of metabolism of ethanol in the rat. American Journal of Physiology, 1956, 186, 380-382.

Belenko, S., \& Woods, S. C. Effects of concentration sequence on ethanol self-selection in rats. Quarterly Journal of Studies on Alcohol, in press.

Cicero, T. J., Snider, S. R., Perez. V. J., \& Swanson, L. W. Physical dependence on and tolerance to alcohol in the rat. Physiology \& Behavior, 1971, 6, 191-198.

Dajani, R. M., Danielski, J., \& Orten, J. M. The utilization of ethanol II. The alcohol-acetaldehyde dehydrogenase systems in the livers of alcohol-treated rats. Journal of Nutrition, $1963,80,196-204$.

Eriksson, K. Genetic selection for voluntary alcohol consumption in the albino rat. Science, 1968, 159, 739-741.

Figueroa, R. B., \& Klotz, A. P. Alterations of alcohol dehydrogenase and other hepatic enzymes in experimental chronic liver disease. Metabolism, 1962, 11, 1169-1179.

Kalant, H. Absorption, diffusion, distribution and elimination of ethanol: Effects on biological membranes. In B. Kissin and $\mathrm{H}$. Begleiter (Eds.), The biology of alcoholism. Vol. 1. New York: Plenum Press, 1971.

Lester, D., \& Greenberg, L. The determination of ethanol in biological materials. Quarterly Journal of Studies on Alcohol, 1958, 19, 331-335.

Majchrowicz, E., Lipton, M. A., Meek, J. L., \& Hall, L. Effects of chronic ethanol consumption on the clearance of acutely administered ethanol and acetaldehyde from blood in rats. Quarterly Journal of Studies on Alcohol, 1968, 29, 553-557.

McClearn, G. E., Bennett, E. L., Herbert, M., \& Schlesinger, K. Alcohol dehydrogenase activity and previous ethanol consumption in mice. Nature, 1964, 203, 793-794.

Meek, J. L., Majchrowicz, E., \& Lipton, M. A. Rates of $\mathrm{C}^{14} \mathrm{O}_{2}$ production from labeled ethanol, acetate and glucose in alcohol and non-drinking rats. Proceedings of the Society for Experimental Biology \& Medicine, 1967, 126, 379-383.

Myers, R. D., \& Holman, R. B. A procedure for eliminating position habit in preference-aversion tests for ethanol and other fluids. Psychonomic Science, 1966, 5, 6-7.

Revusky, S., \& Garcia, J. Learned associations over long delays. Learning \& Motivation, 1970, 4, 1-84.

Rodgers, D. A. Factors underlying differences in alcohol preference among inbred strains of mice. Psychosomatic Medicine, 1966, 28, 498-513.

Rodgers, D. A. Alcohol preference in mice. In J. Zubin and H. F. Hunt (Eds.), Comparative psychopathology-Animal and human. New York: Grune \& Stratton, 1967.

Rodgers, D. A., \& McClearn, G. E. Alcohol preference of mice. In E. L. Bliss (Ed.), Roots of behavior. New York: Hoeber-Harper, 1962.

Rodgers, D. A., McClearn, G. E., Bennett, E. L., \& Herbert, M. Alcohol preference as a function of its caloric utility in mice. Journal of Comparative \& Physiological Psychology, 1963, 56, 666-672.

Schlesinger, K. Genetic and biochemical correlates of alcohol preference in mice. American Journal of Psychiatry, 1966, $122,767-773$.

Segovia-Riquelme, N., Campos, I., Solodkowska, W., Gonzalez, G., Alvarado, R.. \& Mardones, J. Metabolism of labeled ethanol, acetate, pyruvate, and butyrate in "drinker" and "non-drinker" rats. Journal of Biological Chemistry, 1962, 237, 2038-2040.

Segovia-Riquelme, N., Vitale. J. J., Hegsted, D. M., \& Mardones, J. Alcohol metabolism in "drinking" and "non-drinking" rats. Journal of Biological Chemistry, 1956, 223, 399.-403.

Thiessen, D. D.. Whitworth. N., \& Rodgers, D. A. Reproductive functions and metabolic capacity as determinants of alcohol preference in C57BL female mice. Journal of Comparative \& Physiological Psychology. 1967, 63, 151-154.

Wilson, E. C. Ethanol metabolism in mice with different levels of hepatic alcohol dehydrogenase. In R. P. Maickel (Ed.). Biochemical factors in alcoholism. Oxford: Pergamon Press, 1967.

Woods, S. C.. Makous, W., \& Hutton. R. A. Temporal parameters of conditioned hypoglycemia. Journal of Comparative \& Physiological Psychology, 1969, 69, 301-307.

(Received for publication January 2. 1973: accepted January 9. 1973.) 